\title{
Survey on Storage of Water for Domestic Use in Underground Reinforced Concrete Tanks: The Case of Brazzaville (Republic of Congo)
}

\author{
Narcisse Malanda, Paul Louzolo-Kimbembe* \\ Laboratory of Civil Engineering and Environmental Engineering, National School of Engineering, \\ University Marien Ngouabi, Brazzaville, Congo \\ Email: ${ }^{*}$ louzkim@yahoo.fr, ${ }^{*}$ louzolokim@gmail.com
}

Received 9 December 2013; revised 9 January 2014; accepted 16 January 2014

Copyright $@ 2014$ by authors and Scientific Research Publishing Inc.

This work is licensed under the Creative Commons Attribution International License (CC BY).

http://creativecommons.org/licenses/by/4.0/

(c) (i) Open Access

\section{Abstract}

The problem of water supply from the public distribution network still poses very serious problems in many cities in developing countries. Intermittent water supply pushes some households to build underground reinforced concrete tanks for water storage to cope with unwanted water breaks. This study that relies on the results of a survey of households in some areas of the city of Brazzaville (Republic of Congo) aims to verify the importance that users attach to the quality of the works constructed. Indeed, the reliability of the tanks resulting in their impermeability to the external environment has a direct impact on the quality of stored water and therefore the use that is made of water daily. Five areas were selected because of their soil moisture. By 256 tanks identified, 143 are made of reinforced concrete and 113 in masonry. The coating materials used to seal the walls are preferably the earthenware tiles $(64 \%$ of tanks), then the Sika cement $(31 \%)$. Food painting (5\%) is only rarely used. However, $66 \%$ of households are not assured of the potability of the water stored. A significant number of households (46\%) think that the stored water could be contaminated with noxious substances seeping from the outside through the walls of the tanks. The issue of sealing of underground water tanks, especially in areas where the water table is shallow, seems concerned users.

\section{Keywords}

Underground Tanks; Watertightness; Reinforced Concrete; Water Storage; Potability; Household

\footnotetext{
${ }^{*}$ Corresponding author.
}

How to cite this paper: Malanda, N. and Louzolo-Kimbembe, P. (2014) Survey on Storage of Water for Domestic Use in Underground Reinforced Concrete Tanks: The Case of Brazzaville (Republic of Congo). Open Journal of Civil Engineering, 4, 13-22. http://dx.doi.org/10.4236/ojce.2014.41002 


\section{Introduction}

In many cities in developing countries, the permanent water supply from the public distribution network is not always adequately insured [1]. It under goes regular water breaks. In the city of Brazzaville (Republic of Congo), to overcome the inconvenience caused by the intermittent supply, many households and especially commercial establishments have opted for a system of water storage in underground tanks, built in reinforced concrete or in masonry. The water is then sent into the building using a suppressor. Also, the storage of water for domestic use in underground tanks, especially in areas with moisture saturated soil and polluted soil, is an interesting issue. It appears that little work has been done in this context. Most studies encountered mainly interested in the analysis of surface water and groundwater [2], hydrochemical assessment, characterization of the quality and Hydrogeochemistry of groundwater [3]-[6]. These studies examine the review of hydrochemical parameters with the help of statistical tools. In our study, it is not about groundwater, but about water stored in underground tanks built in reinforced concrete or in masonry, with rectangular form. The water is collected directly from the network of the National Water Distribution Company (SNDE) or sometimes by buying from private suppliers who deliver with tankers. If the quality of the water collected is not questioned, however, the quality of water stored during a certain time in the tank should be examined. While sealing the walls of the water tank is not effective, there is a real risk of contamination of water by transfer of pathogens from the external environment. In this study, we try to know, at first, the distribution of water tanks in some areas of the city of Brazzaville. Then, using a questionnaire, we collect information from households to assess the value that they place on the quality of water tanks, because the potability of the stored water is closely linked to their construction processes.

\section{Methodology}

A survey was conducted in Brazzaville in October and November 2012, to collect data from users of underground water tanks.

Having established the questionnaire, the method used for data collection was the census, that is to say the passage of investigators in all the streets and all the parcels areas previously targeted as study areas.

This study focused on three main modules:

- Identification of water tanks;

- Knowledge of materials of realization of the tanks;

- Knowledge of potability of water.

The results of the survey are presented in a summary table in which you can make a holistic approach to all areas and a refined approach to each area with the main indicators presented.

The table of survey results is followed by an analytical section.

Note that the survey was conducted thanks to the perspicacity of investigators who, by direct observation, were able to compensate for the reluctance of the water tank users most often suspicious rather than cooperative.

\section{Results and Discussion}

\subsection{Results and Analysis}

We present first the limitation of survey areas and the number of tanks per area in Table 1 .

Data analysis on the results of the survey will be done by considering modules and answers to questions, expressed in absolute numbers and percentages. The following three modules were chosen:

- Identification;

- Knowledge of building materials;

- Knowledge of water potability.

\subsubsection{Identification}

For the identification module, we chose the cutting of areas relative to the relief and habits of people to use as water tanks and water wells. We found low areas watered by small streams, such as Madoukou and La Tsiémé (Figure 1).

In these areas, the water table is shallow, which tempts people to want to dig wells. On the other hand, given the difficulties in the regular supply of water by the National Water Distribution Company (SNDE), some resi- 
Table 1. Overview of survey areas and identification of water underground tanks.

\begin{tabular}{|c|c|c|}
\hline Survey areas & Limitation of survey areas & Observations \\
\hline Area A & $\begin{array}{l}\text { - Tsiémé Market until Jeanne Vialle, Madoukou river, } \\
\text { avenue de France. }\end{array}$ & $\begin{array}{l}3 \text { tanks in masonry and } 21 \text { reinforced } \\
\text { concrete tanks identified }\end{array}$ \\
\hline Area B & $\begin{array}{ll}- & \text { Loutassi avenue; } \\
\text { - } & \text { Madoukou river-10 Francs market; } \\
\text { - } & \text { Madoukou and La Mfoa rivers; } \\
\text { - } & \text { City of Poto-Poto. }\end{array}$ & $\begin{array}{l}37 \text { tanks in masonry and } 61 \text { reinforced concrete } \\
\text { tanks identified, with } 9 \text { wells. }\end{array}$ \\
\hline Area C & $\begin{array}{l}\text { - } \quad \text { Itoumbi-Ouenzé; } \\
\text { - } \quad \text { Avenue de La Tsiemé—La Tsiemé market; } \\
\text { - } \quad \text { Boueta Mbongo street-La Tsiemé river. }\end{array}$ & $\begin{array}{l}12 \text { tanks in masonry and } 40 \text { reinforced } \\
\text { concrete tanks, with } 52 \text { wells were identified. }\end{array}$ \\
\hline Area D & $\begin{array}{ll}\text { - } & \text { Itoumbi roundabout (Cité des } 17 \text { avenue); } \\
\text { - } & \text { Itoumbi street; } \\
\text { - } & \text { BouetaMbongo avenue; } \\
\text { - } & \text { Moukondo Market. }\end{array}$ & $\begin{array}{l}30 \text { tanks in masonry and } 15 \text { reinforced } \\
\text { concrete tanks plus } 8 \text { wells identified. }\end{array}$ \\
\hline \multirow[t]{2}{*}{ Area E } & $\begin{array}{l}\text { - } \quad \text { La Tsiémé cemetery-La Tsiémé river; } \\
\text { - } \quad \text { Mikalou-High School Thomas Sankara ; } \\
\text { - } \quad \text { Talangaï hospital. }\end{array}$ & $\begin{array}{l}31 \text { tanks in masonry and } 6 \text { reinforced } \\
\text { concrete tanks. }\end{array}$ \\
\hline & Total all areas & $\begin{array}{l}256 \text { water tanks including: } \\
\text { - } \quad 113 \text { tanks in masonry; } \\
\text { • } \quad 143 \text { reinforced concrete tanks. }\end{array}$ \\
\hline
\end{tabular}

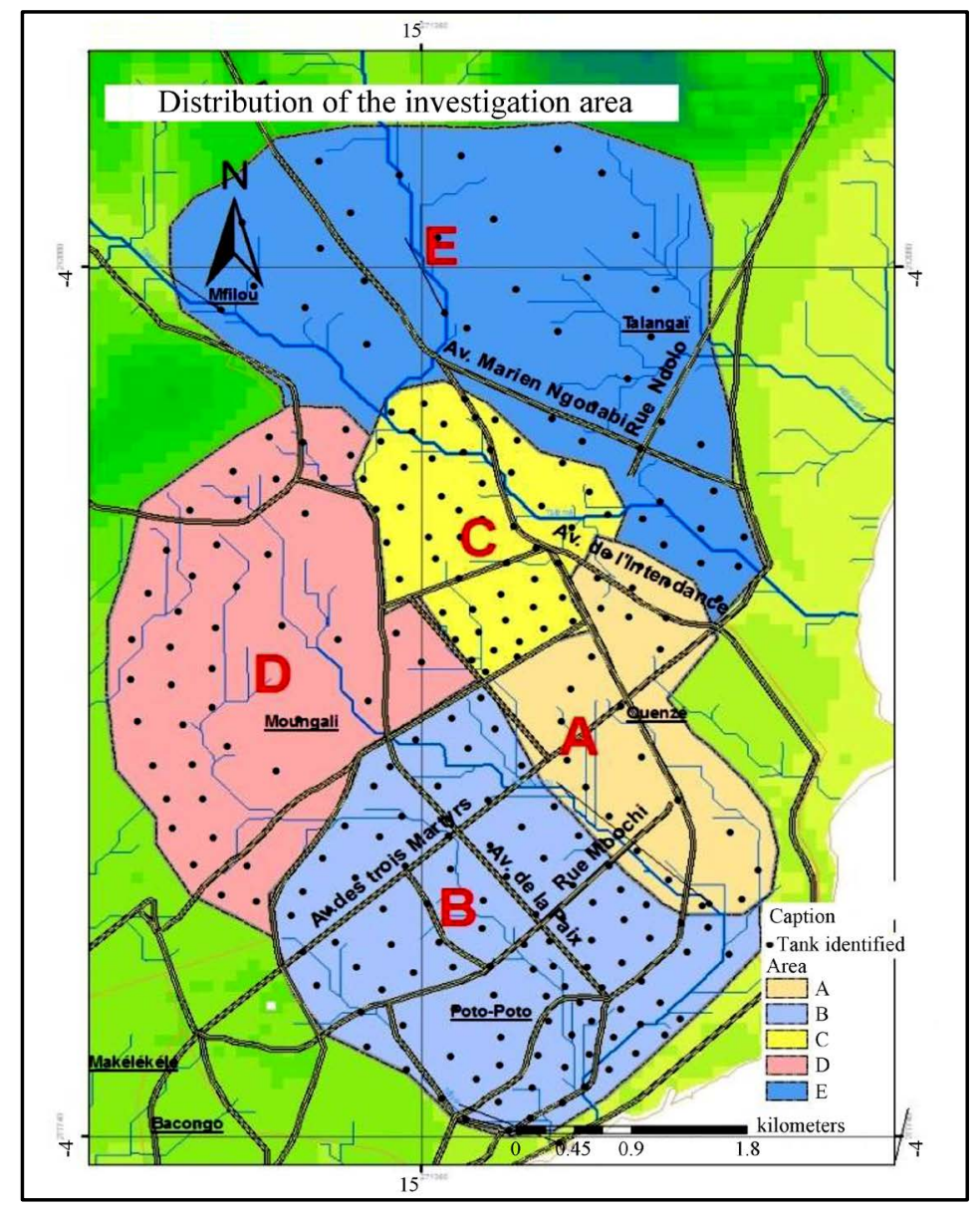

Figure 1. Cartographic representation of investigation areas. Dots $(\bullet)$ represent geographical position of water tanks. 
dents of Brazzaville decided to build underground water tanks.

Note that 256 water tanks in total were identified in localized areas (Table 1). They are unevenly distributed (Figure 2). This is the area B which has the highest number with 98 tanks (38.3\%), followed by the area $\mathrm{C}$ with 52 tanks (20.3\%). The area A has the lowest number with 24 tanks (9.4\%).

\subsubsection{Knowledge of Materials Used for the Construction of Water Tanks}

To better appreciate the importance of the issue, it is necessary to know the type of materials used by households for the construction of water tanks.

Overall, it appears that households build their water tanks preferably in reinforced concrete (56\%), the construction in masonry representing only $44 \%$ of the number of tanks identified in all areas (Figure 3 ).

We can also compare the use of materials in relation to the areas (Figure 4). If in areas A, B and C the use of reinforced concrete is paramount with $8.2 \%, 23.8 \%$ and $15.6 \%$ respectively of households, it should be noted that the construction in masonry prevalent in areas D and $\mathrm{E}$ with $11.7 \%$ and $12 \%$ respectively. However, both types of materials are used in all areas, at various degrees (Table 2).

Regarding the type of materials that were used to seal tanks identified, earthenware tiles are widely preferred with $64.1 \%$, followed by Sika cement and food paint with 30.8\% and 5.1\% respectively (Table 3). In Figure 5 we show the use of sealing materials per area. We show in Table 4 the frequency of use of sealants.

Overall, the tiles are much more used to seal both the reinforced concrete tanks and the masonry in masonry. Sika cement is mainly used for reinforced concrete tanks. Food paint has been selected by a small number of users (Figure 6).

The trade that has more demanded for the realization of the tanks is the worker with $44.5 \%$ of the tanks constructed. However more than half of the tanks were realized by skilled technicians including work technicians with $34 \%$ and engineers with $21.5 \%$ (Figure 7 ).

We find that the most the qualification is higher; less one is called to build tanks. This is certainly due to the much higher fees charged by technicians and engineers. In all areas, engineers are the less demanded for construction of water tanks. The workers come in head in areas B, D and E, while technicians dominate in areas A and C (Figure 8).

Table 2. Results of the survey on water tanks in Brazzaville.

\begin{tabular}{|c|c|c|c|c|c|c|c|c|c|}
\hline & \multirow{2}{*}{$\begin{array}{l}\text { Questions/Answers } \\
\text { Survey } \\
\text { area }\end{array}$} & \multirow{2}{*}{$\begin{array}{c}\text { Water } \\
\text { tank? }\end{array}$} & \multicolumn{2}{|c|}{$\begin{array}{l}\text { Information about the } \\
\text { carrying out of tanks? }\end{array}$} & \multicolumn{2}{|c|}{$\begin{array}{l}\text { Nature of the materials } \\
\text { used to build the tanks? }\end{array}$} & \multicolumn{3}{|c|}{$\begin{array}{l}\text { Qualifying trades who } \\
\text { carried out the work? }\end{array}$} \\
\hline & & & Yes & No & Masonry & $\begin{array}{l}\text { Reinforced } \\
\text { concrete }\end{array}$ & Engineer & Technician & Worker \\
\hline \multirow{2}{*}{ Area A } & Number of tanks & 24 & 13 & 11 & 3 & 21 & 4 & 12 & 8 \\
\hline & Percentage (relative to the total) & $9.4 \%$ & $5 \%$ & $4.3 \%$ & $1.1 \%$ & $8.2 \%$ & $1.6 \%$ & $4.7 \%$ & $3.1 \%$ \\
\hline \multirow{2}{*}{ Area B } & Number of tanks & 98 & 51 & 47 & 37 & 61 & 24 & 35 & 39 \\
\hline & Percentage (relative to the total) & $38.3 \%$ & $20 \%$ & $18.4 \%$ & $14.5 \%$ & $23.8 \%$ & $9.4 \%$ & $13.7 \%$ & $15.3 \%$ \\
\hline \multirow{2}{*}{ Area C } & Number of tanks & 52 & 18 & 34 & 12 & 40 & 13 & 20 & 19 \\
\hline & Percentage (relative to the total) & $20.3 \%$ & $7 \%$ & $13.3 \%$ & $4.7 \%$ & $15.6 \%$ & $5 \%$ & $7.8 \%$ & $7.5 \%$ \\
\hline \multirow{2}{*}{ Area D } & Number of tanks & 45 & 22 & 23 & 30 & 15 & 12 & 11 & 22 \\
\hline & Percentage (relative to the total) & $17.6 \%$ & $8.6 \%$ & $9 \%$ & $11.7 \%$ & $6 \%$ & $4.7 \%$ & $4.3 \%$ & $8.6 \%$ \\
\hline \multirow{2}{*}{ Area E } & Number of tanks & 37 & 24 & 13 & 31 & 6 & 2 & 9 & 26 \\
\hline & Percentage (relative to the total) & $14.4 \%$ & $9.4 \%$ & $5 \%$ & $12 \%$ & $2.4 \%$ & $0.8 \%$ & $3.5 \%$ & $10 \%$ \\
\hline \multirow{2}{*}{$\begin{array}{c}\text { Total all } \\
\text { areas }\end{array}$} & Number of tanks & 256 & 128 & 128 & 113 & 143 & 55 & 87 & 114 \\
\hline & Percentage & $100 \%$ & $50 \%$ & $50 \%$ & $44 \%$ & $56 \%$ & $21.5 \%$ & $34 \%$ & $44.5 \%$ \\
\hline
\end{tabular}




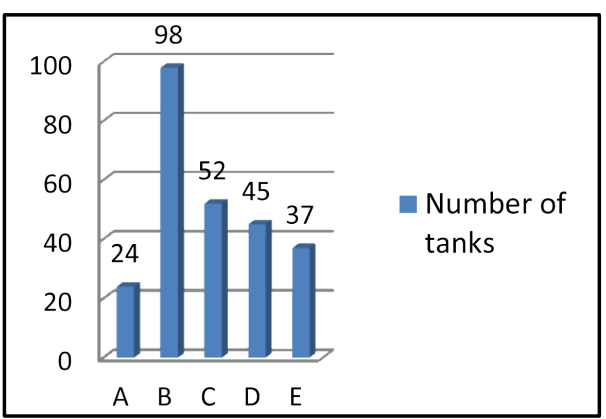

Figure 2. Distribution of tanks per area.

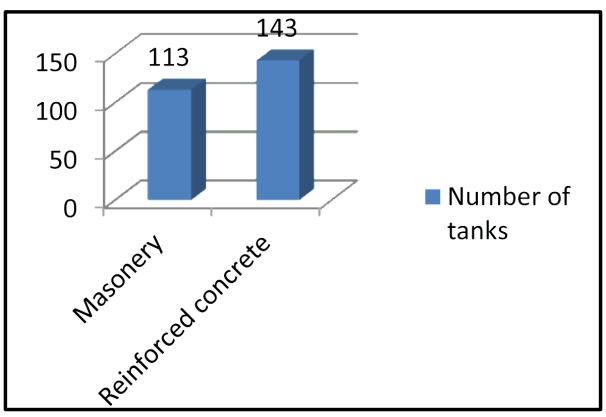

Figure 3. Type of materials used for the construction of water tank.

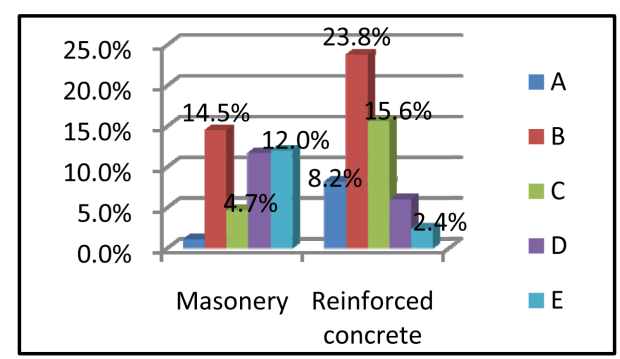

Figure 4. Sort of materials used for the construction of water tank per area.

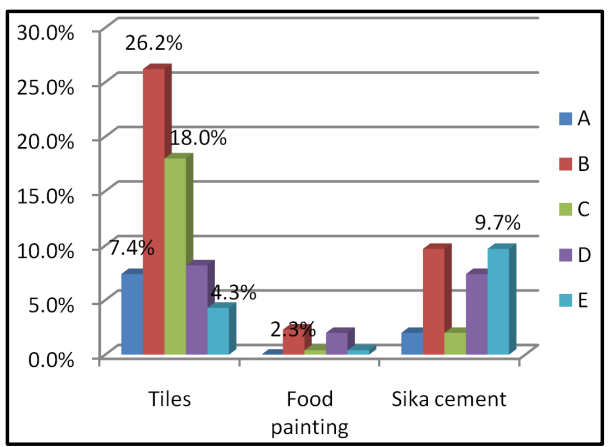

Figure 5. Use of sealing materials per area.

\subsubsection{Knowledge of Potability of Water}

Only $34 \%$ of households are reassured of the potability of the water, against $66 \%$ who are not at all reassured (Table 3).

Outside the area B, and to a lesser extent of the area A, where the majority of households seem confident 
Table 3. Results of the survey on knowledge of potability of water contained in water tanks.

\begin{tabular}{|c|c|c|c|c|c|c|c|c|c|c|c|c|c|c|c|c|c|}
\hline \multirow{2}{*}{\multicolumn{2}{|c|}{$\begin{array}{l}\text { Questions/ } \\
\text { Answers } \\
\text { Survey area }\end{array}$}} & \multicolumn{4}{|c|}{$\begin{array}{c}\text { Type of material } \\
\text { used to seal? }\end{array}$} & \multicolumn{5}{|c|}{$\begin{array}{l}\text { Nature of the water } \\
\text { stored in the tank? }\end{array}$} & \multicolumn{4}{|c|}{ Use of water? } & \multicolumn{3}{|c|}{$\begin{array}{c}\text { Confidence on water } \\
\text { potability? }\end{array}$} \\
\hline & & Tiles & $\begin{array}{c}\text { Food } \\
\text { painting }\end{array}$ & $\begin{array}{c}\text { Sika } \\
\text { cement }\end{array}$ & Total & $\begin{array}{l}\text { Rain } \\
\text { water }\end{array}$ & $\begin{array}{l}\text { SNDE* } \\
\text { water }\end{array}$ & $\begin{array}{c}\text { * Drilling } \\
\text { water }\end{array}$ & $\begin{array}{l}\text { Water } \\
\text { source }\end{array}$ & Total & $\begin{array}{c}\text { Drinking } \\
\text { water }\end{array}$ & $\begin{array}{l}\text { Housework } \\
\text { and cooking }\end{array}$ & $\begin{array}{c}\text { Housework } \\
\text { only }\end{array}$ & k Total & Yes & No & Total \\
\hline \multirow{2}{*}{$\begin{array}{c}\text { Area } \\
\text { A }\end{array}$} & $\begin{array}{l}\text { Number of } \\
\text { tanks }\end{array}$ & 19 & 0 & 5 & 24 & 1 & 18 & 3 & 2 & 24 & 7 & 14 & 3 & 24 & 14 & 10 & 24 \\
\hline & Percentage & $7.4 \%$ & $0 \%$ & $2 \%$ & $9.4 \%$ & $0.4 \%$ & $7 \%$ & $1.2 \%$ & $0.8 \%$ & $9.4 \%$ & $2.7 \%$ & $5.5 \%$ & $1.2 \%$ & $9.4 \%$ & $5.5 \%$ & $3.9 \%$ & $9.4 \%$ \\
\hline \multirow{2}{*}{$\begin{array}{c}\text { Area } \\
\text { B }\end{array}$} & $\begin{array}{l}\text { Number of } \\
\text { tanks }\end{array}$ & 67 & 6 & 25 & 98 & 36 & 21 & 19 & 22 & 98 & 7 & 61 & 30 & 98 & 58 & 40 & 98 \\
\hline & Percentage & $26.2 \%$ & $2.3 \%$ & $9.7 \%$ & $38.3 \%$ & $14.1 \%$ & $68.2 \%$ & $7.4 \%$ & $8.6 \%$ & $38.3 \%$ & $2.7 \%$ & $23.8 \%$ & $11.7 \%$ & $38.3 \%$ & $22.7 \%$ & $15.6 \%$ & $38.3 \%$ \\
\hline \multirow{2}{*}{$\begin{array}{c}\text { Area } \\
\mathrm{C}\end{array}$} & $\begin{array}{l}\text { Number of } \\
\text { tanks }\end{array}$ & 46 & 1 & 5 & 52 & 14 & 18 & 19 & 1 & 52 & 10 & 37 & 5 & 52 & 7 & 45 & 52 \\
\hline & Percentage & $18 \%$ & $0.4 \%$ & $2 \%$ & $20.3 \%$ & $5.5 \%$ & $7 \%$ & $7.4 \%$ & $0.4 \%$ & $20.3 \%$ & $3.9 \%$ & $14.4 \%$ & $2 \%$ & $20.3 \%$ & $2.7 \%$ & $17.6 \%$ & $20.3 \%$ \\
\hline \multirow{2}{*}{$\begin{array}{c}\text { Area } \\
\text { D }\end{array}$} & $\begin{array}{l}\text { Number of } \\
\text { tanks }\end{array}$ & 21 & 5 & 19 & 45 & 8 & 31 & 3 & 3 & 45 & 5 & 34 & 6 & 45 & 6 & 39 & 45 \\
\hline & Percentage & $8.2 \%$ & $2 \%$ & $7.4 \%$ & $17.6 \%$ & $3.1 \%$ & $12.1 \%$ & $1.2 \%$ & $1.2 \%$ & $17.6 \%$ & $2 \%$ & $13.3 \%$ & $2.3 \%$ & $17.6 \%$ & $2.3 \%$ & $15.3 \%$ & $17.6 \%$ \\
\hline \multirow{2}{*}{$\begin{array}{c}\text { Area } \\
\text { E }\end{array}$} & $\begin{array}{l}\text { Number of } \\
\text { tanks }\end{array}$ & 11 & 1 & 25 & 37 & 9 & 6 & 1 & 21 & 37 & 3 & 32 & 2 & 37 & 2 & 35 & 37 \\
\hline & Percentage & $4.3 \%$ & $0.4 \%$ & $9.7 \%$ & $14.4 \%$ & $3.5 \%$ & $2.3 \%$ & $0.4 \%$ & $8.2 \%$ & $14.4 \%$ & $1.2 \%$ & $12.5 \%$ & $0.8 \%$ & $14.4 \%$ & $0.8 \%$ & $13.6 \%$ & $14.4 \%$ \\
\hline \multirow{2}{*}{$\begin{array}{c}\text { Total } \\
\text { all } \\
\text { areas }\end{array}$} & $\begin{array}{l}\text { Number of } \\
\text { tanks }\end{array}$ & 164 & 13 & 79 & 256 & 68 & 94 & 45 & 49 & 256 & 32 & 178 & 46 & 256 & 87 & 169 & 256 \\
\hline & Percentage & $64.1 \%$ & $5.1 \%$ & $30.8 \%$ & $100 \%$ & $26.6 \%$ & $636.7 \%$ & $17.6 \%$ & $19.1 \%$ & $100 \%$ & $12.5 \%$ & $69.5 \%$ & $18 \%$ & $100 \%$ & $34 \%$ & $66 \%$ & $100 \%$ \\
\hline
\end{tabular}

(")SNDE: Water Supply National Company.

Table 4. Frequency of use of sealants for tanks in reinforced concrete and in masonry.

\begin{tabular}{ccc}
\hline Designation & Reinforced concrete & Masonry \\
Tiles & $74(52 \%)$ & $90(80 \%)$ \\
Food painting & $4(3 \%)$ & $9(8 \%)$ \\
Sika cement & $65(45 \%)$ & $14(12 \%)$ \\
Total & $143(100 \%)$ & $113(100 \%)$ \\
\hline
\end{tabular}

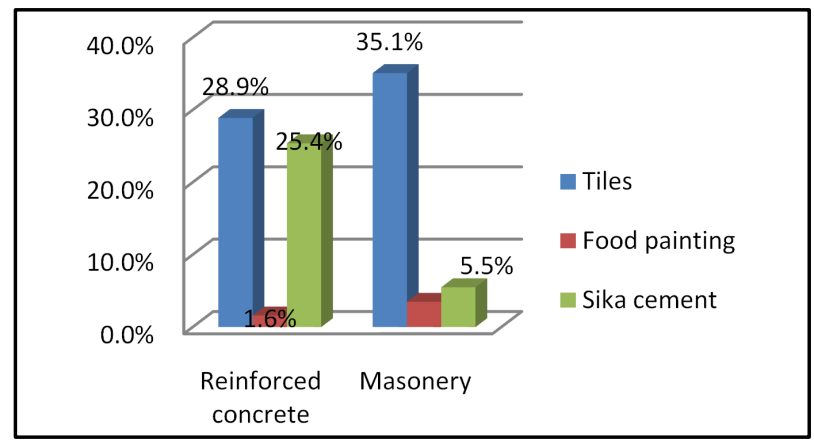

Figure 6. Use of sealing materials for reinforced concrete tanks and masonery tanks. 


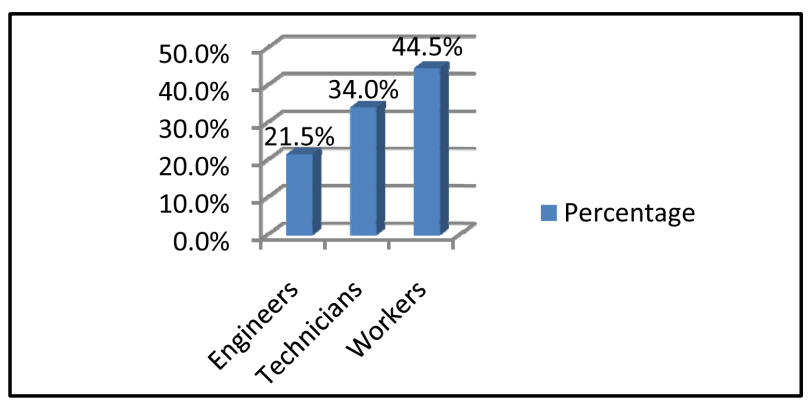

Figure 7. Qualification of trades for the construction of tanks.

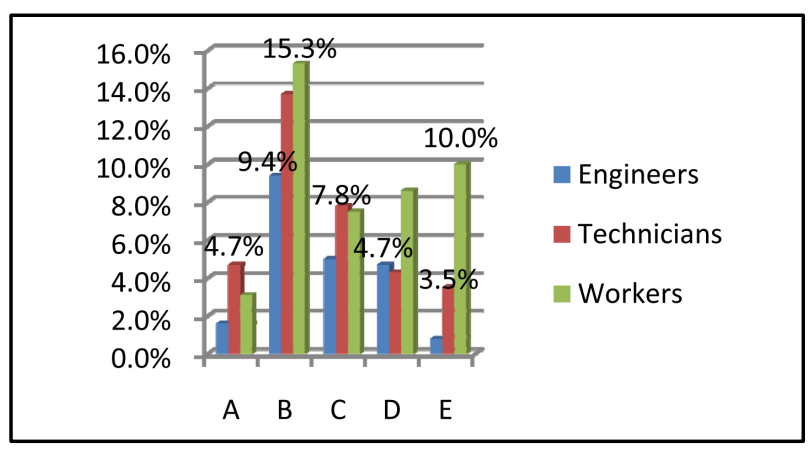

Figure 8. Distribution of trades per area.

about the potability of water tanks; in areas C, D and E households are not reassured of that potability (Figure 9).

Moreover, the largest number of households ignores the fact that environmental conditions can infect the water contained in the tanks (49.6\%). However, those who are aware of the possible contamination of the water by the surrounding external environment are still quite numerous; they represent $46.1 \%$ of the total (Table 5).

We see that in areas A, B and D, households recognize the possibility that the water is infected by the external environment surrounding the tanks (Figure 10).

On the other hand, in the areas $\mathrm{C}$ and $\mathrm{D}$, households in majority seem to do not worry about the possible contamination of the water stored in tanks.

\subsubsection{Use of Water Tanks}

The water stored in tanks is preferably used for the housework and cooking for over $69.5 \%$ of owners (Table 3). Those who use it only for housework represent $18 \%$ of the whole households. The stored water is used as drinking water by only $12.5 \%$ of the proprietors.

It is remarkable that in all areas, households mainly use water stored in tanks for housework and cooking (Figure 11). However, some owners also use it as drinking water and this in all the areas selected for the study.

Regarding the storage duration of the water in the tanks, it appears that the largest number of households store water for 3 to 4 weeks. They represent $52.4 \%$ of the total (Table 5). The percentage of those who store water for a very long time, more than five weeks, is still high (32\%). Only $12 \%$ of households conserve water for a short period (2 weeks). In Figure 12 we have represented the water storage duration in tanks per area.

In all areas except area A, the majority of households store water in tanks for 3 to 4 weeks, thus confirming the general trend.

\subsection{Discussion}

The construction of underground water tanks in reinforced concrete requires the sealing problem is properly solved. In fact, concrete is a porous material by nature and prone to cracking. These two weaknesses led to consider layers or special treatments. The use of a coating of earthenware tiles, which is apparently the most appropriate solution, still leaves many users to be skeptical on the potability of the water stored in tanks. The water- 
Table 5. Results of the survey on the knowledge of the water storage duration in tanks.

\begin{tabular}{|c|c|c|c|c|c|c|c|c|c|c|c|c|}
\hline \multirow{2}{*}{\multicolumn{2}{|c|}{$\begin{array}{l}\text { Questions/Answers } \\
\text { Investigation area }\end{array}$}} & \multicolumn{3}{|c|}{$\begin{array}{l}\text { Justification of water } \\
\text { potability? }\end{array}$} & \multicolumn{4}{|c|}{ Water Storage duration in the tank? } & \multicolumn{4}{|c|}{$\begin{array}{c}\text { Can the natural environmental conditions } \\
\text { infect the water stored in the tanks? }\end{array}$} \\
\hline & & Justified & Unjustified & Total & 2 weeks & $\begin{array}{l}3 \text { to } 4 \\
\text { weeks }\end{array}$ & $\begin{array}{l}\text { More than } \\
5 \text { weeks }\end{array}$ & Total & Yes & No & $\begin{array}{l}\text { Without any } \\
\text { opinion }\end{array}$ & Total \\
\hline \multirow{2}{*}{ Area A } & Number of tanks & 14 & 10 & 24 & 7 & 4 & 13 & 24 & 19 & 3 & 2 & 24 \\
\hline & Percentage & $5.5 \%$ & $3.9 \%$ & $9.4 \%$ & $2.7 \%$ & $1.6 \%$ & $5.1 \%$ & $9.4 \%$ & $7.4 \%$ & $1.2 \%$ & $0.8 \%$ & $9.4 \%$ \\
\hline \multirow{2}{*}{ Area B } & Number of tanks & 98 & 0 & 98 & 9 & 52 & 37 & 98 & 58 & 40 & 0 & 98 \\
\hline & Percentage & $38.3 \%$ & $0 \%$ & $38.3 \%$ & $3.5 \%$ & $20.3 \%$ & $14.4 \%$ & $38.3 \%$ & $22.7 \%$ & $15.6 \%$ & $0 \%$ & $38.3 \%$ \\
\hline \multirow{2}{*}{ Area C } & Number of tanks & 7 & 45 & 52 & 19 & 27 & 6 & 52 & 16 & 27 & 9 & 52 \\
\hline & Percentage & $2.7 \%$ & $17.6 \%$ & $20.3 \%$ & $7.4 \%$ & $10.6 \%$ & $2.3 \%$ & $20.3 \%$ & $6.3 \%$ & $10.5 \%$ & $3.5 \%$ & $20.3 \%$ \\
\hline \multirow{2}{*}{ Area D } & Number of tanks & 6 & 39 & 45 & 2 & 30 & 13 & 45 & 23 & 22 & 0 & 45 \\
\hline & Percentage & $2.3 \%$ & $15.2 \%$ & $17.6 \%$ & $0.8 \%$ & $11.7 \%$ & $5.1 \%$ & $17.6 \%$ & $9 \%$ & $8.6 \%$ & $0 \%$ & $17.6 \%$ \\
\hline \multirow{2}{*}{ Area E } & Number of tanks & 2 & 35 & 37 & 3 & 21 & 13 & 37 & 2 & 35 & 0 & 37 \\
\hline & Percentage & $0.8 \%$ & $13.6 \%$ & $14.4 \%$ & $1.2 \%$ & $8.2 \%$ & $5.1 \%$ & $14.4 \%$ & $0.8 \%$ & $13.6 \%$ & $0 \%$ & $14.4 \%$ \\
\hline \multirow{2}{*}{$\begin{array}{l}\text { Total all } \\
\text { areas }\end{array}$} & Number of tanks & 127 & 129 & 256 & 40 & 134 & 82 & 256 & 118 & 127 & 11 & 256 \\
\hline & Percentage & $49.6 \%$ & $50.4 \%$ & $100 \%$ & $15.6 \%$ & $52.4 \%$ & $32 \%$ & $100 \%$ & $46.1 \%$ & $49.6 \%$ & $4.3 \%$ & $100 \%$ \\
\hline
\end{tabular}

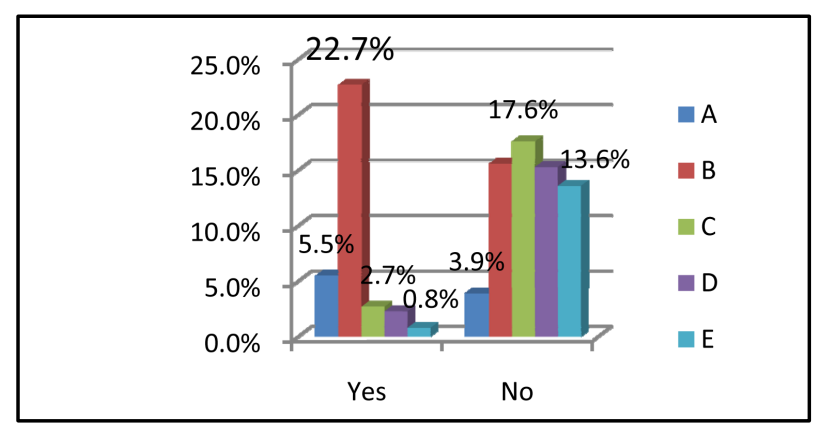

Figure 9. Confidence on the potability of water tank per area.

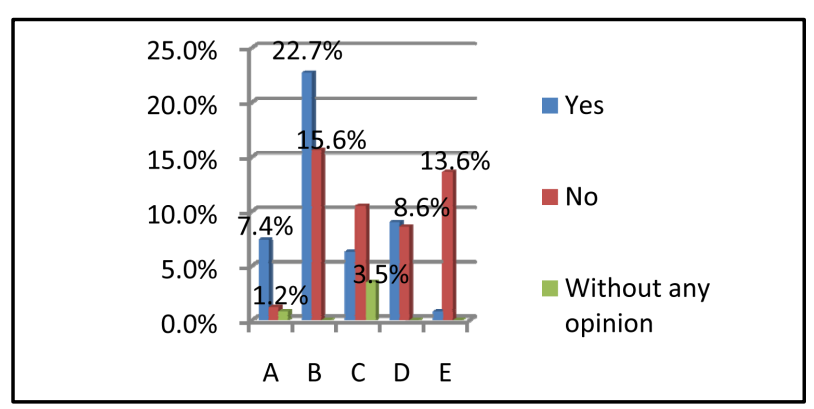

Figure 10. Knowledge of the possibility of water tank infection.

tightness of the tanks could be damaged in two types:

- The stripping of the coating;

- Cracks, classified into three types of categories: accidental cracks, withdrawal cracks, cracks under normal operating stresses. 


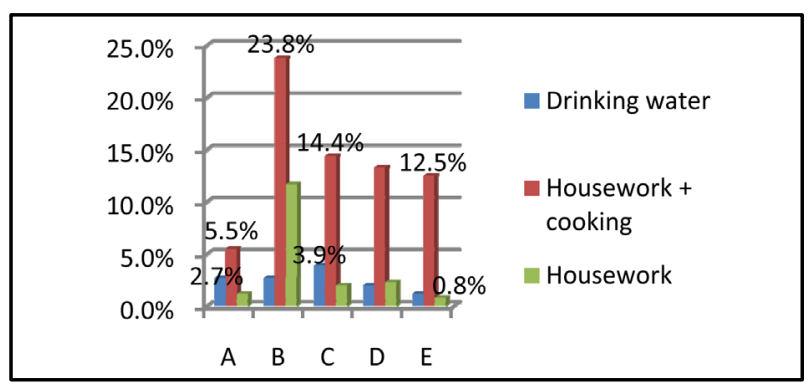

Figure 11. Use of water stored in tanks per area.

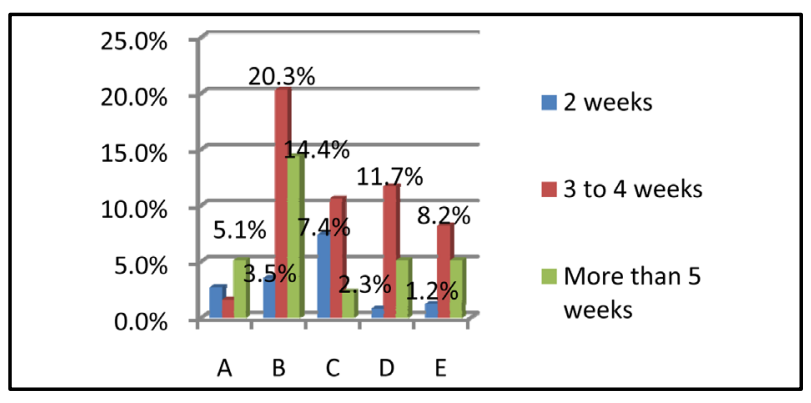

Figure 12. Water storage duration in tanks per area.

Stripping of the coating and the cracks are mainly due to the technological choice of materials, formulation, implementation and cure.

Infiltration of external elements that may contaminate the water stored in tanks are possible mainly through the cracks, as it is recognized that the concrete itself could be considered watertight [7]. We understand why for tanks constructed in masonry, more vulnerable to infiltration, sealing is provided almost exclusively with earthenware tiles (35.1\% of tanks), compared to Sikacement (5.5\%) and painting food (3.5\%).

The lack of scientific publications touching on the type of studied topic in this work does not allow a comparison with any previous results, as we would wish.

\section{Conclusions}

On the whole, reinforced concrete tanks (56\%) are preferred to those that constructed in masonry. The workers are the trade that carry out the most of work (44.5\% of tanks), far ahead of the engineers (21.5\% of tanks) and technicians (34\% of the tanks). This important disqualification could have a direct impact on the quality of tanks built. For sealing the earthenware tiles are the most used with about $64 \%$ of the water tanks sealed. Despite these precautions to make the walls of the tanks to be tight, $66 \%$ of households suspect the potability of water stored. A significant number of households (46\%) fear a possible contamination of the stored water by infiltration of noxious substances through the walls of the tanks. So, the stored water is it used by the immense majority of households (88\%) only for cooking and/or housework. There are only $12 \%$ of owners who use it as drinking water.

It would be interesting to examine the hydro-chemical parameters of the water stored in underground tanks, which would be a way to prove the infiltration of outside elements, especially in areas where the soil is very wet. Given the difficulty of ensuring a hermetic sealing of reinforced concrete tanks, it could be recommended to install the tanks height rather than bury them.

\section{References}

[1] Vaishnav, M.M. and Dewangan, S. (2012) Analytical and Statistical Evaluation of Surface and Sub-Surface Water of BALCO Industrial Area, Korba, C. G., India. International Journal of Environmental Sciences, 2, 1369-1379. http://dx.doi.org/10.6088/ijes.00202030023

[2] Matini, L., Moutou, J.M. and Kongo-Mantono, M.S. (2009) Evaluation Hydro-Chimique des Eaux Souterraines en 
Milieu Urbain au Sud-Ouest de Brazzaville, Congo. Afrique Science, 5, 82-98.

[3] Mahmood, A., Muqbool, W. and Mumtaz, M.W. (2011) Application of Multivariate Statistical Techniques for the Characterization of Ground Water Quality of Lahore, Gujranwala and Sialkot (Pakistan). Pakistan Journal of Analytical \& Environmental Chemistry, 12, 102-112.

[4] Liu, C.-W., Lin, K.-H. and Kuo, Y.-M. (2003) Application of Factor Analysis in the Assessment of Groundwater Quality in a Blackfoot Disease Area in Taiwan. The Science of the Total Environment, Elsevier, 77-89. http://dx.doi.org/10.1016/S0048-9697(02)00683-6

[5] Sharaky, A.M., Atta, S.A., El Hassanein, A.S. and Khallal, K.M.A. (2007) Hydrogeochemistry of Groundwater in the Western Nile Delta Aquifers, Egypt. 2nd International Conference of the Geology of Tethys, Cairo, 19-21 March, 29 p.

[6] Dalton, M.G. and Upchurch, S.B. (1978) Interpretation of Hydrochemical Facies by Factor Analysis. Ground Water, 16, 228-233. http://dx.doi.org/10.1111/j.1745-6584.1978.tb03229.x

[7] Mivelaz, P. (1996) Etanchéité des Structures en Béton Armé: Fuite à Travers un Elément Fissuré. Ph.D. Thesis, Ecole Polytechnique Fédérale de Lausanne, Suisse, 213 p. 